\title{
Convenient Preparation and Spectroscopic Characterization of 7R-Hydroxymatairesinol
}

\author{
Eleonora Colombo ${ }^{1}$, Giuseppe Paladino ${ }^{2}$, Umberto Ciriello ${ }^{2}$ and Daniele Passarella ${ }^{1, *(\mathbb{C})}$ \\ 1 Dipartimento di Chimica, Università degli Studi di Milano, 20133 Milano, Italy; eleonora.colombo@unimi.it \\ 2 Linnea S.A., 6595 Riazzino, Switzerland; gpaladino@linnea.ch (G.P.); uciriello@linnea.ch (U.C.) \\ * Correspondence: daniele.passarella@unimi.it
}

check for
updates

Citation: Colombo, E.; Paladino, G.; Ciriello, U.; Passarella, D. Convenient Preparation and Spectroscopic

Characterization of

7R-Hydroxymatairesinol. Molecules 2021, 26, 5838. https://doi.org/ $10.3390 /$ molecules 26195838

Academic Editors: Constantinos

Athanassopoulos, Carlo Siciliano and Marcello Locatelli

Received: 24 August 2021

Accepted: 22 September 2021

Published: 26 September 2021

Publisher's Note: MDPI stays neutral with regard to jurisdictional claims in published maps and institutional affiliations.

Copyright: (c) 2021 by the authors. Licensee MDPI, Basel, Switzerland. This article is an open access article distributed under the terms and conditions of the Creative Commons Attribution (CC BY) license (https:// creativecommons.org/licenses/by/ $4.0 /)$.

\begin{abstract}
The preparation of 7R-HMR (allo-hydroxymatairesinol) is reported by: (a) $\mathrm{NaBH}_{4}$ kinetic reduction of $7 R / 7 S$ diastereomeric mixture; and (b) epimerization of the $C 7$ hydroxyl group by Mitsunobu reaction and subsequent ester hydrolysis. The availability of highly pure target compound (7R-HMR) made it possible to confirm the structure of the target compound and to complete the full spectroscopic characterization.
\end{abstract}

Keywords: 7-hydroxymatairesinol (HMR); allo-hydroxymatairesinol; lignans; Picea abies

\section{Introduction}

Lignans are a large group of low molecular weight polyphenols, derived by oxidative coupling of monolignols. They are plant secondary products and present many different biological activities including anticancer, antioxidant, antimicrobial, anti-inflammatory, and immunosuppressive [1]. Many plant lignans are constituents of human nutrition, present in flax and sesame seeds in high concentrations and in whole grain cereals, beans, other vegetables, some fruits and berries, wines, tea, and coffee in lower concentrations [2]. Until recently, flaxseeds were considered one of the richest sources of lignans. However, Norway spruce (Picea abies) branch stubs (or knots) have been shown to be extremely rich in them [3]. They contain on average about $10 \%$ by weight of lignans of which (-)-7Shydroxymatairesinol (7S-HMR) makes up 70-85\% [4]. 7S-HMR occurs not only in spruce knots but is the dominant lignan in cereals-such as in wheat, triticale, oat, barley, millet and corn bran-and in amaranth whole grain [5]. Its presence in cereals was not detected in previous studies because of inadequate analytical methods using either acidic or alkaline treatment steps where 7S-HMR is converted primarily to conidendrin or conidendric acids, respectively [3]. Methods for the separation of spruce knots and isolation of 7S-HMR have been developed, making it the most readily available lignan [6].

7S-HMR has been shown to metabolize to (-)-enterolactone by intestinal bacteria in rats and humans and to have chemopreventive effects on the development of DMBA induced mammary carcinoma in rats $[7,8]$. It has also been shown to have a chemopreventive effect in the ApcMin mice model of human familial adenomatous polyposis [9]. Furthermore, it has been shown to be a strong antioxidant and able to reduce the oxidation of LDL-particles in vitro [8]. It has been marketed as a nutritional supplement since 2006 [10].

7S-HMR is accompanied by a stereoisomer differing in stereo-chemistry at C7. The major isomer is $\left(7 S, 8 R, 8^{\prime} R\right)-(-)-7$-hydroxymatairesinol while the minor is $\left(7 R, 8 R, 8^{\prime} R\right)-(-)$ hydroxymatairesinol ( $7 R$-HMR), that is reported also as allo-HMR. In the average extract the $7 S / 7 R$ ratio is around 3:1. In the literature, no full characterization and full assignment of the minor stereoisomer is reported due to its difficult separation from its main diastereomer. We were thus interested in an efficient synthesis of $7 R-H M R$ to obtain it in a pure form and complete its characterization.

In this paper, two approaches to the obtainment of pure $7 R-H M R$ are presented: the first is an enrichment of $7 R-H M R$ taking advantage of the different kinetic of reduction of 
the two diastereomers, while the second is an epimerization of the hydroxylic group in position C7, de facto converting 7S-HMR into 7R-HMR by Mitsunobu reaction. The full characterization and assignment of $7 R-H M R$ is reported.

\section{Results}

\subsection{Enrichment of $7 R-H M R$ (2) in the Extract Mixture}

The used starting mixture contained a ratio of 7S-HMR/7R-HMR around 2:3.8. This derives by repeated extraction/purification processes of 7S-HMR of the plant extract. As a difference in the kinetic of reduction between the two diastereomers is known [3], the reaction of said mixture with $\mathrm{NaBH}_{4}$ was attempted (Scheme 1). 7S-HMR was expected to be almost quantitatively transformed to (-)-matairesinol (1), whereas the other isomer (7R) should show only partial conversion at the same conditions. Several attempts were carried out in order to only obtain $7 R$-HMR and $7 S-H M R$ in the reaction mixture, that can be more easily separated.<smiles>[R]Oc1ccc(C[C@H]2C(=O)OC[C@H]2[C@H](O)c2ccc(O)c(OC)c2)cc1OC</smiles><smiles>[R][R][X]</smiles><smiles>COc1cc(C[C@@H]2COC(=O)[C@H]2Cc2ccc(O)c(OC)c2)ccc1O</smiles>

1

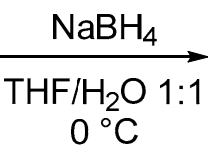<smiles>COc1cc(C[C@H]2C(=O)OC[C@@H]2[C@H](O)c2ccc(O)c(OC)c2)ccc1O</smiles>

7R-HMR

Scheme 1. Enrichment of $7 R-H M R$ by hydride reduction.

The best attempt using around $0.7 \mathrm{~g}$ of substrate led after $4 \mathrm{~h}$ to a mixture of 7S-HMR $(1.2 \%), 7 R$-HMR $(12.5 \%)$, and $\mathbf{1}(31.1 \%)$. The mixture was purified through successive chromatographies, until the obtainment of $100 \mathrm{mg}$ of a $7 R$-HMR that contains around $6 \%$ of 7S-HMR. The reaction was monitored by HPLC (Table 1 and Figure 1) that gave us the possibility to perfectly distinguish the peaks of the target compounds. The optimized conditions were then applied for a reaction on larger scale of substrate (54 g) and the results appeared consistent with the small-scale reaction. The main problem of this procedure is the appearance of unknown byproducts that compromise the purification process and requires several repeated purification steps. 
Table 1. HPLC monitoring of the reduction reaction after $15 \mathrm{~h}$.

\begin{tabular}{|c|c|c|c|}
\hline & \multicolumn{3}{|c|}{ Area \% } \\
\hline & 7S-HMR (rt = $19.7 \mathrm{~min})$ & $7 R-\mathrm{HMR}(\mathrm{rt}=21.7 \mathrm{~min})$ & $1(\mathrm{rt}=51.3 \mathrm{~min})$ \\
\hline $20 \mathrm{~min}$ & 12.60 & 20.95 & 1.30 \\
\hline $50 \mathrm{~min}$ & 9.59 & 19.20 & 1.47 \\
\hline $2 \mathrm{~h}$ & 5.17 & 13.76 & 1.39 \\
\hline $3 \mathrm{~h}$ & 4.59 & 19.61 & 1.57 \\
\hline $4 \mathrm{~h}$ & 1.2 & 12.5 & 31.1 \\
\hline $15 \mathrm{~h}$ & 0 & 0 & 27.76 \\
\hline
\end{tabular}

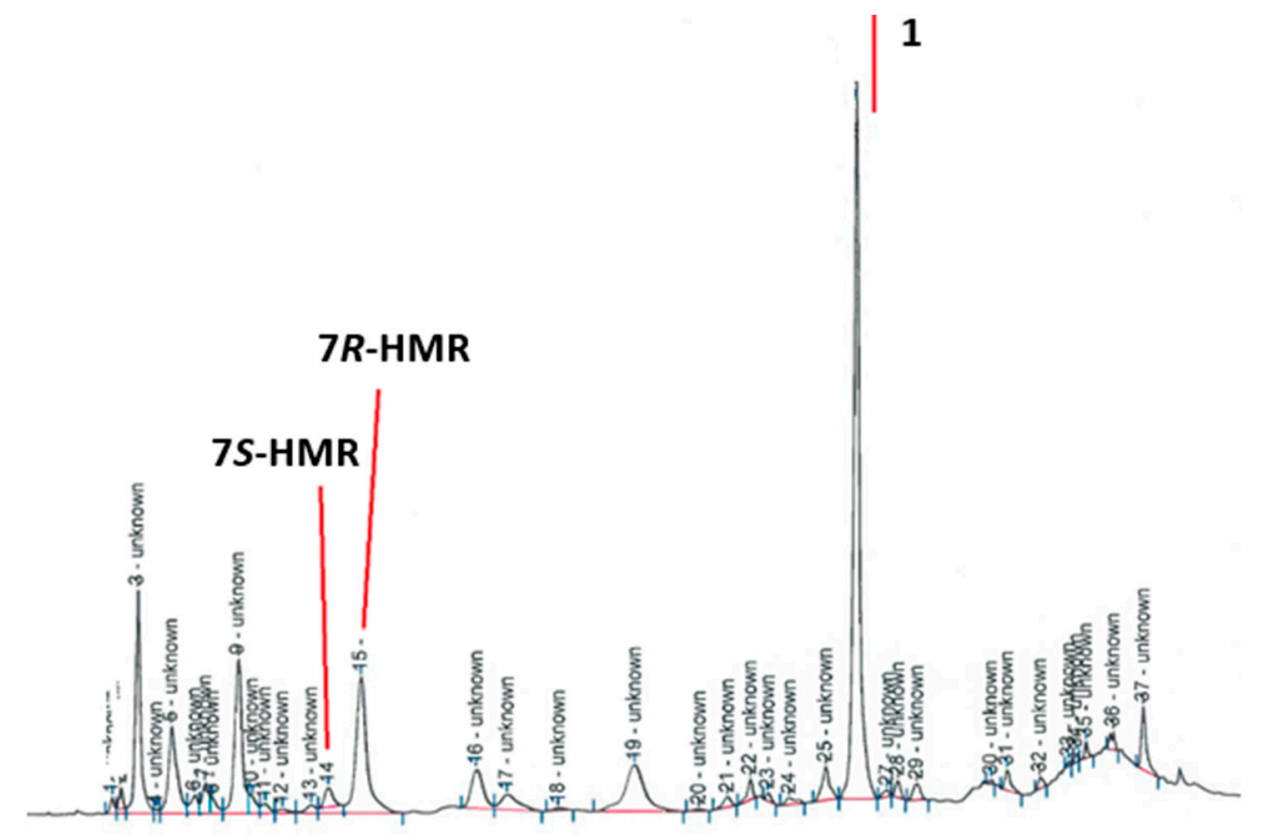

Figure 1. HPLC chromatogram relative to the reaction after $3.5 \mathrm{~h}$.

\subsection{Conversion of $7 S-H M R$ in $7 R-H M R$}

In the second approach we developed an inversion of the $\mathrm{C} 7$ configuration using modified Mitsunobu conditions (Scheme 2).<smiles>COc1ccc(C[C@@H]2C(=O)OC[C@@H]2O)cc1OC</smiles>

7S-HMR<smiles>COc1cc(C[C@H]2C(=O)OC[C@H]2[C@H](O)c2ccc(O)c(OC)c2)ccc1O</smiles>

$7 R$-HMR

Scheme 2. Conversion of 7S-HMR into 7R-HMR by Mitsunobu strategy.

Below (Scheme 3) reports the procedure for the preparation of desired compound $7 R$-HMR, performed optimizing the strategy previously reported by Fischer et al. [11]. 
<smiles>COc1cc(C[C@H]2C(=O)OC[C@@H]2[C@@H](O)c2ccc(O)c(OC)c2)ccc1O</smiles>

7S-HMR<smiles>COc1ccc(C[C@H]2C(=O)OC[C@@H]2[C@H](O)c2ccc(OC(C)(C)C)c(OC)c2)cc1OC</smiles>

2

1. $\mathrm{PPh}_{3}, p$-nitrobenzoic acid

DIAD, THF, rt, $24 \mathrm{~h}$

2. $\mathrm{K}_{2} \mathrm{CO}_{3} 20 \% \mathrm{w} / \mathrm{v}, \mathrm{MeOH}$, $\mathrm{rt}, 1 \mathrm{~h}$

$43 \%$<smiles>COc1cc(C[C@H]2C(=O)OC[C@@H]2[C@@H](O)c2ccc(O)c(OC)c2)ccc1O</smiles>

7R-HMR<smiles>COc1ccc(C[C@@H]2C(=O)OC[C@@H]2[C@H](O)c2ccc(OC(C)(C)C)c(OC)c2)cc1OC</smiles>

3

Scheme 3. Synthetic strategy for preparation of $7 R-H M R$.

Starting from 7S-HMR the first reaction we performed was the selective protection of the phenolic hydroxyl groups at $\mathrm{C} 4$ and $\mathrm{C} 4^{\prime}$ to block their acidic behavior that could interfere with the subsequent Mitsunobu reaction. The reaction took place at room temperature and the exact control of the temperature was found to be crucial to avoid the contamination of compounds deriving from not selective undesired reactions. The second step involves the inversion of the C7 hydroxy group of 7S-HMR exploiting the efficacy of Mitsunobu reaction. This reaction was carried out with diisopropyl azodicarboxylate (DIAD) that is considered safer than diethyl azodicarboxylate (DEAD). The obtained ester of the $p$-nitrobenzoic acid was then hydrolyzed to guarantee the obtainment of the corresponding secondary alcohol with the desired configuration at position C7. The formation of the ester intermediate was evaluated by ${ }^{1} \mathrm{H}-\mathrm{NMR}$ analysis, appearing to be a single compound. In particular, a downfield shift of proton H-7 signal ( $\delta 5.8 \mathrm{ppm}$, doublet) was observed, proving the inversion of configuration at $\mathrm{C}$. In the final step for the preparation of compound $7 R-H M R$, we removed the TBS protecting groups. Once again, the control of the reaction conditions and in particular the control of the temperature resulted crucial for the success of the reaction. The use of the conditions reported in the literature [11] gave very low yield with insuperable problems in the purification process. Decreasing the temperature and in particular reaching $0{ }^{\circ} \mathrm{C}$, we obtained compound $7 R$-HMR in good yields (72\%) and the purification process by flash chromatography gave compound $7 R$-HMR with appreciable purity. We also had the opportunity to confirm that the initial purity of the target compound is compromised by the in solution epimerization due to the thermodynamic stability of the $7 S$ diastereoisomer.

\subsection{Spectroscopic Characterization}

Spectroscopic data for the obtained (-)-7R-HMR are reported below (Table 2). 
Table 2. NMR signal assignment for 7R-HMR and comparison with 7S-HMR chemical shift.<smiles>COc1cc([C@H](c2cccc(O)c2)[C@H]2C(=O)OC[C@@H]2[C@@H](O)c2ccc(O)c(OC)c2)ccc1O</smiles>

\begin{tabular}{|c|c|c|c|c|c|c|}
\hline & \multicolumn{4}{|c|}{ 7R-HMR } & \multicolumn{2}{|c|}{ 7S-HMR } \\
\hline & ${ }^{1} \mathbf{H}$ & & $J(\mathrm{~Hz})$ & ${ }^{13} \mathrm{C}$ & ${ }^{1} \mathbf{H}$ & ${ }^{13} \mathrm{C}$ \\
\hline 1 & & & & 134.0 & & 133.4 \\
\hline 2 & 6.57 & d & 1.8 & 107.9 & 6.67 & 108.2 \\
\hline 5 & 6.85 & $\mathrm{~d}$ & 8.1 & 114.0 & 6.85 & 114.4 \\
\hline 6 & 6.65 & $\mathrm{dd}$ & $8.1 \quad 1.8$ & 119.3 & 6.69 & 118.8 \\
\hline 7 & 4.40 & $\mathrm{~d}$ & 7.8 & 74.4 & 4.63 & 75.3 \\
\hline 8 & $2.49-2.57$ & $\mathrm{~m}$ & & 46.2 & 2.61 & 45.1 \\
\hline 9 & 4.46 & $\mathrm{dd}$ & $\begin{array}{ll}9.5 & 5.5 \\
94 & 74\end{array}$ & 68.4 & $3.90-4.02$ & 68.6 \\
\hline $1^{\prime}$ & 4.20 & $\mathrm{dd}$ & & 129.3 & & 129.5 \\
\hline $2^{\prime}$ & 6.45 & bs & & 111.0 & 6.61 & 111.9 \\
\hline $3-\mathrm{OCH}_{3}$ & 3.78 & $\mathrm{~s}$ & & & 3.81 & \\
\hline $3^{\prime}-\overline{\mathrm{OCH}_{3}}$ & 3.81 & $\mathrm{~s}$ & & 55.7 & 3.85 & 55.9 \\
\hline $5^{\prime}$ & 6.79 & $\mathrm{~d}$ & 7.9 & 113.9 & 6.79 & 114.0 \\
\hline $6^{\prime}$ & 6.50 & $\mathrm{dd}$ & $\begin{array}{ll}7.9 & 1.9\end{array}$ & 121.9 & 6.60 & 122.5 \\
\hline $7^{\prime}$ & $2.68-2.83$ & $\mathrm{~m}$ & & 35.0 & $2.90-3.05$ & 35.1 \\
\hline $8^{\prime}$ & $2.49-2.58$ & $\mathrm{~m}$ & & 46.2 & $2.90-2.98$ & 43.7 \\
\hline $9^{\prime}$ & & & & 179.0 & & 179.3 \\
\hline 3 & & & & 146.9 & & 146.8 \\
\hline 4 & & & & 145.7 & & 146.6 \\
\hline $3^{\prime}$ & & & & 146.7 & & 145.5 \\
\hline $4^{\prime}$ & & & & 144.8 & & 144.4 \\
\hline $3-\mathrm{OH}$ & 5.57 & $\mathrm{~b}$ & & & 5.55 & \\
\hline $3^{\prime}-O \underline{H}$ & 5.67 & $\mathrm{~b}$ & & & 5.65 & \\
\hline 7-O $\underline{H}$ & 1.98 & $\mathrm{~b}$ & & & 1.91 & \\
\hline
\end{tabular}

The obtained compound has been purified by chromatography and then submitted to spectroscopic characterization in order to confirm the target structure. All the ${ }^{1} \mathrm{H}$ - and ${ }^{13} \mathrm{C}-\mathrm{NMR}$ signals were assigned on the base of COSY, HSQC, and HMBC spectra. The crucial signal is the one at $4.40 \mathrm{ppm}(\mathrm{d}, J=7.8 \mathrm{~Hz})$ that is due to $\mathrm{H}-7$ and its corresponding ${ }^{13} \mathrm{C}$ C7 signal at $74.4 \mathrm{ppm}$ (HETCORR spectrum). By HMBC spectrum, it is possible to identify the signal of carbons C2 (107.9 ppm) and C6 (119.3 ppm) with the corresponding protons (6.57 and 6.65 respectively). With the use of COSY spectrum the signals of H-5, the corresponding C5 (by HETCORR) and the spin system of the other phenyl group were identified and assigned. $\mathrm{H}-7^{1} \mathrm{H}$ signal appears connected (COSY) with the signal at 2.48-2.57 ppm (H-8). The crosspeaks of $\mathrm{H}-8$ confirmed the presence of the signals due to $\mathrm{H}_{2}-9$ at (4.46 and $4.20 \mathrm{ppm}$ ) and the signal due to $\mathrm{H}-8^{\prime}$ (2.49-2.58 ppm). H-8' appears directly connected (COSY) with $\mathrm{H}_{2}-7^{\prime}(2,68-2,83 \mathrm{ppm})$. Some of these interactions are shown below (Figure 2). The HETCORR made the assignment of all the corresponding carbon signals possible. See Supplementary Materials for the complete spectra. 

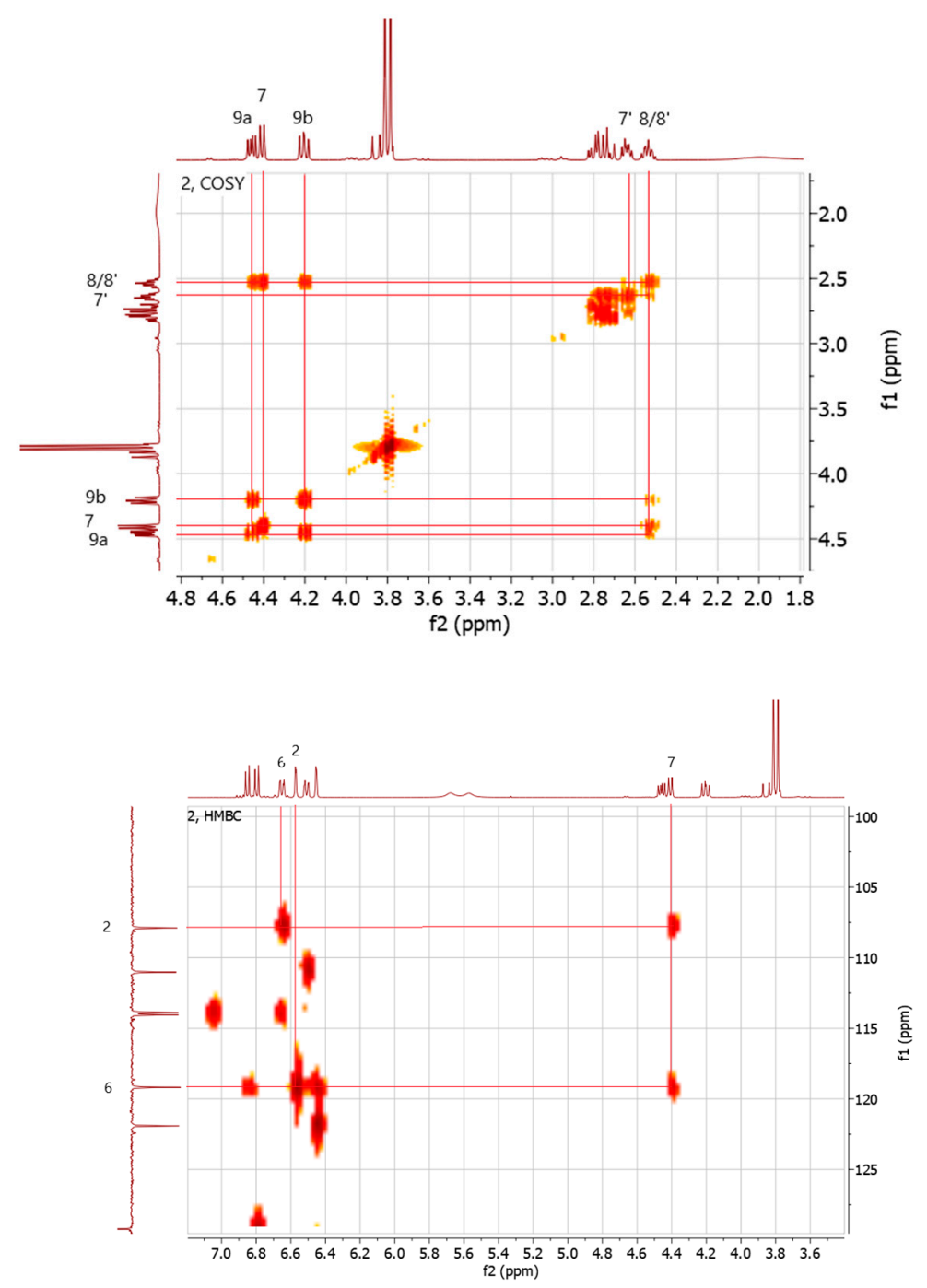

Figure 2. Most relevant COSY and HMBC interactions for 7R-HMR structure elucidation.

The NMR spectra are strictly related to the ones of the corresponding C7 epimer (7S-HMR) used as starting material. In particular, the chemical shift of the signal due to H-7 moves from 4.63 (7S-HMR) to $4.40 \mathrm{ppm}$ (7R-HMR) and this evidence confirms the different interactions of $\mathrm{H}-7$ within the space of the molecule deriving from the inversion of the configuration and the obtainment of the diastereoisomer $7 R$. The evaluation of the purity of the obtained compounds is monitored by HPLC analysis (Discovery HSF5 $25 \mathrm{~cm} \times 21.2 \mathrm{~mm} \times 10 \mu \mathrm{m}$ ) with an eluent composed by two solutions 78:22 respectively composed by $\mathrm{H}_{2} \mathrm{O}$ with $0.1 \% \mathrm{HCOOH}$ and $\mathrm{CH}_{3} \mathrm{CN} / \mathrm{MeOH}(3: 7) 0.1 \% \mathrm{HCOOH}$ and using $20 \mathrm{~mL} / \mathrm{min}$ flux. The same conditions have been used for semipreparative purification of limited quantity of $7 S-H M R$.

\section{Materials and Methods}

Plant extracts, 7S-HMR/7R-HMR mixture and pure 7S-HMR have been furnished by Linnea SA (Via Cantonale CH, 6595 Riazzino (TI), Switzerland).

${ }^{1} \mathrm{H}-\mathrm{NMR}$ spectra were recorded on Bruker DRX-400 And Bruker DRX-300 instruments and are reported relative to residual $\mathrm{CDCl}_{3} .{ }^{13} \mathrm{C}-\mathrm{NMR}$ spectra were recorded on the same instruments (101 and $75 \mathrm{MHz}$ ) and are reported relative to $\mathrm{CDCl}_{3}$. Chemical shifts ( $\delta)$ for proton and carbon resonances are quoted in parts per million (ppm) relative to tetramethylsilane (TMS), which was used as an internal standard. 
HR-ESI mass spectra were recorded on FT-ICR APEXII (Bruker Daltonics, Billerica, MA, USA). Specific rotations were measured with a P-1030-Jasco polarimeter with $10 \mathrm{~cm}$ optical path cells and $1 \mathrm{~mL}$ capacity (Na lamp, $\lambda=589 \mathrm{~nm}$ ).

\subsection{Reduction Reaction of a Diasteroisomeric Mixture of $7 S$ - and $7 R-H M R$}

$0.766 \mathrm{~g}$ (2.04 mmol) of 7S-HMR/7R-HMR around 2:3.8 were dissolved in a 1:1 mixture of THF and $\mathrm{H}_{2} \mathrm{O}(40 \mathrm{~mL})$. The mixture was cooled at $0{ }^{\circ} \mathrm{C}$ and $\mathrm{NaBH}_{4}(0.389 \mathrm{~g}, 10.2 \mathrm{mmol})$ was added portion wise, the reaction was then monitored by HPLC (see Table 1). After leaving it overnight at $\mathrm{rt}$, the reaction was quenched by adding aqueous $10 \% \mathrm{HCl}(3.5$ $\mathrm{mL}$ ) until reaching $\mathrm{pH} \approx 4-5$ and the mixture was extracted with $\mathrm{CH}_{2} \mathrm{Cl}_{2}$. The organic layer was washed with $\mathrm{H}_{2} \mathrm{O}$, dried over $\mathrm{Na}_{2} \mathrm{SO}_{4}$, filtered, and evaporated under reduced pressure to obtain a brown oil $(530 \mathrm{mg})$.

\subsection{Reduction of 7S-HMR on Multigram Scale}

$50.45 \mathrm{~g}$ (134.9 mmol) of 7S-HMR/7R-HMR around 2:3.8 were dissolved in a 1:1 mixture of $\mathrm{THF}$ and $\mathrm{H}_{2} \mathrm{O}(500 \mathrm{~mL})$. The mixture was cooled at $0{ }^{\circ} \mathrm{C}$ and $\mathrm{NaBH}_{4}(12.63 \mathrm{~g}, 333.9$ mmol) was added portion wise, the reaction was then monitored by HPLC (Table 3). After leaving it for $4 \mathrm{~h}$ at $0{ }^{\circ} \mathrm{C}$ the reaction was quenched by adding aqueous $10 \% \mathrm{HCl}$ until reaching $\mathrm{pH} \approx 5$ and the mixture was extracted with $\mathrm{CH}_{2} \mathrm{Cl}_{2}(2 \times 250 \mathrm{~mL})$. The organic layer was washed with $\mathrm{H}_{2} \mathrm{O}(2 \times 100 \mathrm{~mL})$, dried over $\mathrm{Na}_{2} \mathrm{SO}_{4}$, filtered and evaporated under reduced pressure to obtain a brown oil (29.52 g).

Table 3. HPLC monitoring of the reduction reaction after $3.5 \mathrm{~h}$.

\begin{tabular}{cccc}
\hline Time & Area $\%$ \\
\hline & 7S-HMR & 7R-HMR & $\mathbf{1}$ \\
\hline $2 \mathrm{~h}$ & 4.59 & 19.61 & n.d. \\
\hline $3.5 \mathrm{~h}$ & 1.2 & 12.5 & 31.09 \\
\hline
\end{tabular}

Silica chromatography purification: $10 \mathrm{~g}$ of the reaction mixture were submitted to purification through gravimetric silica chromatography $\left(\mathrm{SiO}_{2} 120 \mathrm{~g}\right)$. Dry loading $\left(\mathrm{SiO}_{2} \approx 12 \mathrm{~g}\right)$, column diameter $=3.5 \mathrm{~cm}, \mathrm{~h}=24 \mathrm{~cm}, 60 \mathrm{~mL}$ fractions. Eluent: gradient from $\mathrm{CH}_{2} \mathrm{Cl}_{2}: \mathrm{MeOH} 100: 1$ to $25: 1$. $7 R$-HMR was obtained $(1.7 \mathrm{~g})$ with $89 \%$ purity (11\% is due to 7S-HMR).

Subsequent HPLC preparative columns are performed: Column: Discovery HSF5 $25 \mathrm{~cm} \times 21.2 \mathrm{~mm} \times 10 \mu \mathrm{m}$. FMA: $\mathrm{H}_{2} \mathrm{O}+0.1 \%$ HCOOH-FMB: ACN/MeOH (3:7) + 0.1\% HCOOH-Premixed (2.0 L) FMA/FMB 78/22, flux: $20 \mathrm{~mL} / \mathrm{min} .850 \mathrm{mg}$ of starting mixture gave $100 \mathrm{mg}$ of $7 R$-HMR with $94.2 \%$ purity (5.8\% is due to $7 S-H M R)$

\subsection{Preparation of (-)-bis-TBS-7S-HMR (2)}

TBSCl $(0.420 \mathrm{~g}, 2.79 \mathrm{mmol})$ and imidazole $(0.453 \mathrm{~g}, 6.65 \mathrm{mmol})$ are added to a solution of (-)-7S-HMR (0.500 g, $1.34 \mathrm{mmol})$ in DMF (5.1 mL) at rt.

The reaction mixture was stirred for $4 \mathrm{~h}$ then washed with saturated aqueous $\mathrm{NaHCO}_{3}$ and brine and dried over anhydrous sodium sulfate. The solvent was removed in vacuo and the crude material was purified by flash chromatography (Hexane/EtOAc 8:2) to give title compound as colorless oil $(0.550 \mathrm{~g}, 68 \%$ yield $)$.

${ }^{1} \mathrm{H}-\mathrm{NMR}\left(400 \mathrm{MHz}, \mathrm{CDCl}_{3}\right): \delta 6.81(\mathrm{~d}, J=8.1 \mathrm{~Hz}, 1 \mathrm{H}), 6.78-6.44(\mathrm{~m}, 5 \mathrm{H}), 4.58(\mathrm{~d}$, $J=6.8 \mathrm{~Hz}, 1 \mathrm{H}), 3.92-3.83(\mathrm{~m}, 2 \mathrm{H}), 3.78(\mathrm{~s}, 3 \mathrm{H}), 3.75(\mathrm{~s}, 3 \mathrm{H}), 3.13(\mathrm{dd}, J=13.2,4.9 \mathrm{~Hz}, 1 \mathrm{H})$, 3.07-2.97 (m, 1H), 2.94-2.78 (m, 1H), 2.62-2.54 (m, 1H), $0.97(\mathrm{~s}, 9 \mathrm{H}), 0.95(\mathrm{~s}, 9 \mathrm{H}), 0.13(\mathrm{~s}, 6 \mathrm{H})$, $0.11(\mathrm{~s}, 6 \mathrm{H}) \mathrm{ppm}$.

${ }^{13} \mathrm{C}-\mathrm{NMR}\left(100 \mathrm{MHz}_{\mathrm{CDCl}}\right)$ : $\delta 179.3,151.3,150.9,145.3,143.8,135.0,131.1,122.1,121.0$

120.7, 118.4, 113.6, 109.9, 75.2, 68.2, 55.5, 55.4, 45.1, 43.8, 35.0, 25.7, 18.4, -4.6 ppm.

$[a]_{D}^{20}=-1.58\left(\right.$ c $\left.1, \mathrm{CHCl}_{3}\right)$.

HR-ESI-MS: MW 625.2993 calcd. for $\mathrm{C}_{32} \mathrm{H}_{50} \mathrm{O}_{7} \mathrm{Si}_{2} \mathrm{Na}$, MW 625.3001 found. 


\subsection{Preparation of (+)-bis-TBS-7S-HMR (3)}

DIAD ( $0.5 \mathrm{~mL}, 2.58 \mathrm{mmol})$, p-nitrobenzoic acid $(0.431 \mathrm{~g}, 2.58 \mathrm{mmol})$ and triphenylphosphine $(0.677 \mathrm{~g}, 2.58 \mathrm{mmol})$ were added to a solution of the TBS protected 7S-HMR (2) $(0.519 \mathrm{~g}, 0.860 \mathrm{mmol})$ in anhydrous THF $(21.5 \mathrm{~mL})$ at $\mathrm{rt}$. The mixture was stirred at $\mathrm{rt}$ overnight then the solvent was removed in vacuo. The p-nitrobenzoate was purified by flash chromatography (Hexane/AcOEt 8:2) then dissolved in methanol $(7.5 \mathrm{~mL})$ and treated with an aqueous solution of $\mathrm{K}_{2} \mathrm{CO}_{3}(0.36 \mathrm{~mL}, 20 \% \mathrm{w} / \mathrm{v})$. After $1 \mathrm{~h}$, the mixture was diluted with diethyl ether and washed with saturated aqueous $\mathrm{NH}_{4} \mathrm{Cl}$. The organic phase was separated, and the aqueous phase was extracted with diethyl ether. The combined organic phases were dried over anhydrous sodium sulfate and the solvent was removed in vacuo. The product was purified by flash chromatography (Hexane/AcOEt 8:2) to give title compound as a colourless oil $(0.225 \mathrm{~g}, 43 \%)$.

${ }^{1} \mathrm{H}-\mathrm{NMR}\left(300 \mathrm{MHz}, \mathrm{CDCl}_{3}\right): \delta 6.79(\mathrm{~d}, J=8.1 \mathrm{~Hz}, 1 \mathrm{H}), 6.72(\mathrm{~d}, J=7.8 \mathrm{~Hz}, 1 \mathrm{H}), 6.65(\mathrm{~d}$, $J=2.0 \mathrm{~Hz}, 1 \mathrm{H}), 6.60-6.58(\mathrm{~m}, 2 \mathrm{H}), 6.47(\mathrm{dd}, J=8.1,2.0 \mathrm{~Hz}, 1 \mathrm{H}), 4.39(\mathrm{dd}, J=6.6,2.2 \mathrm{~Hz}, 1 \mathrm{H})$, $4.29(\mathrm{dd}, J=9.3,7.1 \mathrm{~Hz}, 1 \mathrm{H}), 3.98(\mathrm{dd}, J=8.1,8.1 \mathrm{~Hz}, 1 \mathrm{H}), 3.77(\mathrm{~s}, 3 \mathrm{H}), 3.74(\mathrm{~s}, 3 \mathrm{H}), 2.85-2.67$ $(\mathrm{m}, 3 \mathrm{H}), 2.58-2.47(\mathrm{~m}, 1 \mathrm{H}), 0.98(\mathrm{~s}, 9 \mathrm{H}), 0.97(\mathrm{~s}, 9 \mathrm{H}), 0.12(\mathrm{~s}, 6 \mathrm{H}), 0.11(\mathrm{~s}, 6 \mathrm{H}) \mathrm{ppm}$.

${ }^{13} \mathrm{C}-\mathrm{NMR}\left(100 \mathrm{MHz}^{\mathrm{CDCl}} 3\right): \delta 180.0,151.3,151.0,145.1,143.9,135.1,130.9,121.5$, 121.0, 120.7, 118.1, 112.9, 109.5, 74.1, 67.9, 55.4, 46.1, 43.3, 34.7, 25.7, 18.4, -4.6 ppm.

$[a]_{D}^{20}=+8.11$ (c $\left.0.50, \mathrm{CHCl}_{3}\right)$.

HR-ESI-MS: MW 625.2993 calcd. for $\mathrm{C}_{32} \mathrm{H}_{50} \mathrm{O}_{7} \mathrm{Si}_{2} \mathrm{Na}$, MW 625.3004 found.

\subsection{Preparation of (-)-7R-HMR}

To a solution of the (+)-bis-TBS-7R-HMR (3) $(1.12 \mathrm{~g}, 1.86 \mathrm{mmol})$ in THF $(50 \mathrm{~mL})$ and acetic acid $(0.41 \mathrm{~mL}, 7.44 \mathrm{mmol})$ was added TBAF $(7.44 \mathrm{~mL}, 1 \mathrm{M}$ in THF, $7.44 \mathrm{mmol})$ at $0{ }^{\circ} \mathrm{C}$. The reaction mixture was stirred at $0^{\circ} \mathrm{C}$ for $2 \mathrm{~h}$, then washed with saturated aqueous $\mathrm{NH}_{4} \mathrm{Cl}$ and extracted with diethyl ether. The organic extracts were combined and the solvent was removed in vacuo. The residue was purified by flash chromatography (Hexane/ AcOEt 1:1), giving $7 R$-HMR as a colorless oil $(0.500 \mathrm{~g}, 72 \%)$.

${ }^{1} \mathrm{H}-\mathrm{NMR}\left(400 \mathrm{MHz}, \mathrm{CDCl}_{3}\right): \delta 6.82(\mathrm{~d}, J=8.0 \mathrm{~Hz}, 1 \mathrm{H}), 6.76(\mathrm{~d}, J=7.9 \mathrm{~Hz}, 1 \mathrm{H}), 6.63(\mathrm{dd}$, $J=8.1,1.9 \mathrm{~Hz}, 1 \mathrm{H}), 6.54(\mathrm{~d}, J=1.9 \mathrm{~Hz}, 1 \mathrm{H}), 6.47(\mathrm{dd}, J=8.0,1.9 \mathrm{~Hz}, 1 \mathrm{H}), 6.42(\mathrm{~d}, J=1.9 \mathrm{~Hz}$, $1 \mathrm{H}), 5.67(\mathrm{bs}, 1 \mathrm{H}), 5.57(\mathrm{bs}, 1 \mathrm{H}), 4.43(\mathrm{dd}, J=9.5,5.6 \mathrm{~Hz}, 1 \mathrm{H}), 4.38(\mathrm{~d}, J=7.8 \mathrm{~Hz}, 1 \mathrm{H}), 4.22$ $(\mathrm{dd}, J=9.5,7.6 \mathrm{~Hz}, 1 \mathrm{H}), 3.79(\mathrm{~s}, 3 \mathrm{H}), 3.74(\mathrm{~s}, 3 \mathrm{H}), 2.79-2.72(\mathrm{~m}, 2 \mathrm{H}), 2.65-2.59(\mathrm{~m}, 1 \mathrm{H})$, 2.54-2.47 (m, 1H), 1.98 (bs, 1H) ppm.

${ }^{13} \mathrm{C}-\mathrm{NMR}\left(100 \mathrm{MHz}, \mathrm{CDCl}_{3}\right): \delta 179.0,146.9,146.7,145.7,144.8,134.0,129.3,121.9$, $119.3,114.0,113.9,111.0,107.9,74.4,68.4,55.7,46.2,35.0 \mathrm{ppm}$.

$[a]_{D}^{20}=-3.45\left(\mathrm{c} 0.10, \mathrm{CHCl}_{3}\right)$.

7S-HMR $[a]_{D}^{20}=-13.3$ (c 4, THF)

HR-ESI-MS: MW 397.1263 calcd. for $\mathrm{C}_{20} \mathrm{H}_{22} \mathrm{O}_{7} \mathrm{Na}$, MW 397.1271 found.

\section{Conclusions}

The use of two different approaches to obtain $7 R$-HMR gave us the opportunity to confirm - with high accuracy - the structure of the target compound and to have enough high purity compound available to complete its full and detailed spectroscopic characterization.

Supplementary Materials: Spectroscopic data relative to $7 R$-HMR, compounds $\mathbf{2}$ and $\mathbf{3}$ are available online, Figure S1: ${ }^{1} \mathrm{H}-\mathrm{NMR}$ relative to $7 R$-HMR, Figure S2: COSY relative to $7 R$-HMR, Figure S3: HSQC relative to $7 R$-HMR, Figure S4: HMBC relative to $7 R$-HMR, Figure S5: ${ }^{13} \mathrm{C}-\mathrm{NMR}$ relative to $7 R$-HMR, Figure S6: ${ }^{1} \mathrm{H}-\mathrm{NMR}$ relative to compound 2, Figure S7: ${ }^{13} \mathrm{C}-\mathrm{NMR}$ relative to compound 2, Figure S8: ${ }^{1} \mathrm{H}-\mathrm{NMR}$ relative to compound 3, Figure S9: ${ }^{13} \mathrm{C}-\mathrm{NMR}$ relative to compound 3.

Author Contributions: Conceptualization, D.P., U.C.; methodology, E.C., G.P.; investigation, E.C., G.P., U.C.; resources, D.P., U.C.; data curation, D.P., U.C., G.P., E.C.; writing-original draft preparation, E.C., D.P.; writing—review and editing, E.C., D.P., G.P., U.C.; supervision, D.P., U.C.; project 
administration, D.P., U.C.; funding acquisition, D.P. All authors have read and agreed to the published version of the manuscript.

Funding: This research received no external funding.

Institutional Review Board Statement: Not applicable.

Informed Consent Statement: Not applicable.

Data Availability Statement: Not applicable.

Conflicts of Interest: The authors declare no conflict of interest. The funders had no role in the design of the study; in the collection, analyses, or interpretation of data; in the writing of the manuscript, or in the decision to publish the results.

Sample Availability: Samples of the compounds are available from the authors.

\section{References}

1. Saleem, M.; Hyoung, J.K.; Ali, M.S.; Yong, S.L. An update on bioactive plant lignans. Nat. Prod. Rep. 2005, 25, 696-716. [CrossRef] [PubMed]

2. Smeds, A.I.; Eklund, P.C.; Sjöholm, R.E.; Willför, S.M.; Nishibe, S.; Deyama, T.; Holmbom, B.R. Quantification of a broad spectrum of lignans in cereals, oilseeds, and nuts. J. Agric. Food Chem. 2007, 55, 1337-1346. [CrossRef] [PubMed]

3. Eklund, P.C.; Sundell, F.J.; Smeds, A.I.; Sjöholm, R.E. Reactions of the natural lignan hydroxymatairesinol in basic and acidic nucleophilic media: Formation and reactivity of a quinone methide intermediate. Org. Biomol. Chem. 2004, 2, $2229-2235$. [CrossRef] [PubMed]

4. Willför, S.; Hemming, J.; Reunanen, M.; Eckerman, C.; Holmbom, B. lignans and lipophilic extractives in norway spruce knots and stemwood. Holzforschung 2003, 57, 27-36. [CrossRef]

5. Spilioti, E.; Holmbom, B.; Papavassiliou, A.G.; Moutsatsou, P. Lignans 7-Hydroxymatairesinol and 7-Hydroxymatairesinol 2 exhibit anti-inflammatory activity in human aortic endothelial cells. Mol. Nutr. Food. Res. 2014, 58, 749-759. [CrossRef] [PubMed]

6. Willför, B.; Holmbom, C.; Eckerman, J.; Hemming, M.; Reunanen, K.; Sundberg, S. A Method for Isolating Phenolic Substances or Juvabiones from Wood Comprising Knotwood. U.S. Patent WO2002098830A1, 16 May 2002.

7. Saarinen, N.M.; Wärri, A.; Mäkelä, S.I.; Eckerman, C.; Reunanen, M.; Ahotupa, M.; Salmi, S.M.; Franke, A.A.; Kangas, L.; Santti, R. hydroxymatairesinol, a novel enterolactone precursor with antitumor properties from coniferous tree (picea abies). Nutr. Cancer 2000, 36, 207-216. [CrossRef] [PubMed]

8. Kangas, L.; Saarinen, N.; Mutanen, M.; Ahotupa, M.; Hirsinummi, R.; Unkila, M.; Perälä, M.; Soininen, P.; Laatikainen, R.; Korte, H.; et al. antioxidant and antitumor effects of hydroxymatairesinol (hm-3000, hmr), a lignan isolated from the knots of spruce. Eur. J. Cancer Prev. 2002, 11, S48-S57. [PubMed]

9. Oikarinen, S.I.; Pajari, A.M.; Mutanen, M. chemopreventive activity of crude hydroxsymatairesinol (HMR) extract in Apc(Min) Mice. Cancer Lett. 2000, 161, 253-258. [CrossRef]

10. Holmbom, B.; Willfoer, S.; Hemming, J.; Pietarinen, S.; Nisula, L.; Eklund, P.; Sjoeholm, R. Materials, Chemicals, and Energy from Forest Biomass. In Knots in Trees: A Rich Source of Bioactive Polyphenols; American Chemical Society Publishing: Cham, Switzerland, 2007; pp. 350-362.

11. Fischer, J.; Reynolds, A.J.; Sharp, L.A.; Sherburn, M.S. Radical Carboxyarylation Approach to Lignans. Total Synthesis of (-)-Arctigenin, (-)-Matairesinol, and Related Natural Products. Org. Lett. 2004, 6, 1345-1348. [CrossRef] [PubMed] 